\title{
Applying Knowledge Management Principles to Preserve Iranian Arts
}

\author{
Tannaz Shahnezadegan \\ Teacher and researcher of Iranian traditional
}

\author{
Mahmoud Manafi \\ Doctor of business administration
}

\begin{abstract}
Art is one of the most important heritages of past generations that which is transferred by artists from one generation to another. A lot of artists due to different reasons are not able to share their art with others. This paper aims to use existed principles in knowledge management in order to identify factors which are crucial for preserving the Iranian Arts. By the previous, the most important knowledge management practices consist of knowledge transferring, knowledge storing, knowledge generating, and knowledge applying. However, the outcomes of the interview adapt the knowledge management practices for preserving existing arts.
\end{abstract}

Keywords: Knowledge Management, Iran, Art, knowledge transferring, knowledge storing, knowledge generating, and knowledge applying

\section{INTRODUCTION}

Art is one of the critical topics for which we can use existed concepts in knowledge management in order to improve it. A lot of artists in history had no academic education and after their death many secrets of their art have not been transferred to next generation. Hence, employing such principles can remarkably contribute to preserve arts as well as experiences of artists.

Iran as the oldest country around the world due to its long history, is known as the cradle of many different arts and sciences. Different kingdoms and also attack of other countries led to initiation of various arts in this country which are not necessary to be presented in this paper. However, one of the main challenges during past 100 years is the improper management of heritage arts. Most of the old artists in fields of art crafts or music have passed away or are not willing to share their arts and experiences with others.

According to mentioned points above, this research firstly attempts to highlight existed principles in knowledge management. Later, the aim is to adapt these principles in knowledge management with arts.

\section{LITERATURE REVIEW}

Knowledge management (KM) emerged in $19^{\text {th }}$ century and is a well-developed subject in both business and academic contexts. According to knowledge management principles, globally, the organizations generate and implement knowledge management principles in order to improve business process efficiency, increase quality and productivity of services and also identify new products and services for customers (Nguyen and Mohamed, 2011).

In addition, in field of technology, usually innovation is a direct consequence of knowledge management effectiveness (Darroch and McNaughton, 2002; Du Plessis, 2007; Manafi and Subramaniam, 2015) and also is due to being one of the key objectives to establish knowledge-creating organizations in order to improve their competitive advanatages (Nonaka and Takeuchi, 1995).

\subsection{Knowledge Management and Knowledge-Based Theories}

Recent studies conducted in management and economic contexts are contributing to provide a knowledge-based theory of the organization that explores main reasons for existence of companies to create, integrate and utilize knowledge (Grant, 1996; Kogutand Zander, 1992). The knowledge based view $(\mathrm{KBV})$ is initiated according to resource based view of the company that concentrates on strategic properties as the key source of having competitive advantage (Amit and Schoemaker, 1993). On the other side, based on KBV, knowledge is the key strategic resource that if managed appropriately, allows the organization to generate value from its production exploitation (DeCarolis and Deeds, 1999; Zack, McKeen and Singh, 2009; Donate and de Pablo, 2015). In addition, the company in fact is the manifestation of knowledge bearing entity which can manage its existed knowledge resources via its combinative dynamic abilities (Kogut and Zander, 1992). Moreover, as noted by Argote and Ingram (2000). "the challenge for those who are willing to create competitive advantage for their firm would be, however, in business strategy context, a lot of effort goes for understanding knowledge as the fundamental base of competitive advantage compared to explaining how firms can generate, retain and also transfer knowledge."

Thus, organizations should establish and perform a set of different initiatives or activities to contribute enhance their organizational abilities and exploit values; it means that they should employ knowledge management practices (Grant, 2002). The key goal of organizations utilizing knowledge management is to obtain knowledge awareness both collectively and individually and then form itself in such a way to efficiently and effectively employ organization's knowledge which is gained. According to Alavi and Leidner (2001), using the knowledge management practices, generally based on information and communication technologies (ICTs), results in positive organizational consequences for example improved communications and higher participation levels among employees, efficient problem solving and also effective time-to-market, better financial performance, improved marketing practices as well as better team performance in projects, so the widespread contribution of knowledge management leads to overall success of an organization. In addition, for technology intensive industries 
in which competitive advantage significantly depends on the organizational ability to develop new processes and products continually, innovation appears to be the most critical issue for knowledge management (Nonaka and Takeuchi, 1995; Raisch and Birkinshaw, 2008; Subramaniam and Youndt, 2005).

\subsection{Knowledge Management Practices}

Knowledge management is a series of initiatives, activities and also strategies which organizations utilize to create, keep, transfer and use knowledge for organizational performance improvement (Alavi and Leidner, 2001; Zack et al., 2009). Mainly, explorative initiatives attempt to generate new knowledge while exploitative practices seek to utilize existing knowledge through transferring, sharing and applying those resources (Grant, 2002; March, 1991).

Knowledge creation includes generating new knowledge content or to replace existing content in tacit or explicit knowledge pool of the organization (Alavi and Leidner, 2001). Knowledge management initiation activities usually are relevant to internal knowledge development via $R \& D$ (Darroch and McNaughton, 2002). In addition, while organizations are generating knowledge and learn, they might lose track or forget the obtained knowledge (Alavi and Leidner, 2001). Therefore, storage activities of knowledge management that involve organization, structure and organizational knowledge retrieval, allow companies to keep an organizational memory that includes knowledge which can reside in different forms for instance stored information in electronic databases, written documentation, codified stored human knowledge in expert systems, tacit knowledge or processes achieved by individuals or groups and also documented organizational processes (Donate and de Pablo, 2015; Alavi and Tiwana, 2003; Zack, 1999).

In addition, knowledge management activities for transfer allows the employees to share, replicate and disseminate information into those places that require and can have good impacts on existing knowledge of companies. Therefore, the organization has to set up communication channels that might be formal, informal or impersonal (Alavi and Leidner, 2001). Lastly, knowledge application contributes integrating the knowledge from various sources to improve organizational capability via mechanisms which are according to norms, routines or decision-making in particular occasions (Grant, 1996). Knowledge management application practices therefore should concentrate on application and also integration of existing knowledge to organizational activities and solving the problems effectively and easier for the organization (Grant, 1996; Zack et al. 2009; Donate and de Pablo, 2015).

Effective knowledge management in previous studies is explained as a technique to improve innovation capacity of the organization. For example, according to an extensive study of reviewing relationship between $\mathrm{KM}$ and innovation, Darroch and McNaughton (2002) noted that in general, KM generation practices have relationship with innovation performance. Therefore, many scholars identified that there is a positive relationship between $\mathrm{R} \& \mathrm{D}$ efforts to create new ideas and innovation (Capon, Lehman and Hulbert, 1992; Zahra and Bogner, 1999). Other studies also revealed that there is a positive relationship between innovation and market knowledge acquisition or employees' knowledge ( $\mathrm{Li}$ and Calantone, 1998; Lynn, Reilly and Akgun, 2000).
Based on such conclusions, KM practices which promote the new knowledge generation and also organizational learning are necessary for reaching the advantages according to innovation (Zack et al., 2009). Generally, such practices deal with learning via concerted variation processes, play and planned experimentation (Baum, $\mathrm{Li}$ and Usher, 2000). KM according to internal $\mathrm{R} \& \mathrm{D}$ practices to create knowledge (hiring and training research personnel, investing in equipment and research project evaluation) is so critical for the company to promote its innovation performance.

\section{RESEARCH METHOD AND RESULTS}

This research applied qualitative approach to adapt the best knowledge management practices for the existing art. By literature review, there are four main practices for knowledge management namely, knowledge generating, knowledge transferring, knowledge storing, and knowledge applying. So, several open questions were designed. These questions referred to the six experts ( 3 academicians and 3 artists). However, the questions are presented in following:

1. Who can contribute to preserve and improve the existing arts?

2. What are your suggestions for generating new arts or improving them?

3. What ways do you suggest to share the arts and artworks?

4. What methods do you suggest to storage of arts and artworks?

5. How we can exploit the existing arts and also artistical potentials in society?

6. Please mention any kind of suggestions or ideas that you have about arts and artworks.

The achieved results from the interview are mentioned in Table 1 as follows: 
Table 1:

\begin{tabular}{|l|l|}
\hline Questions & Interview Outcomes \\
\hline $\begin{array}{l}\text { Responsibility and } \\
\text { Support }\end{array}$ & $\begin{array}{l}\text { Government, ministry of culture, universities and schools, art } \\
\text { institutes }\end{array}$ \\
\hline Generating & $\begin{array}{l}\text { Identifying the experts, gathering them together, motivating them } \\
\text { to consult and share their experiences. }\end{array}$ \\
\hline Transferring & $\begin{array}{l}\text { Financial support of experts, appreciation and respecting them, } \\
\text { identifying young talents, motivating the young talents to learn. }\end{array}$ \\
\hline Storage & $\begin{array}{l}\text { Employing new technologies such as camerawoork, recording on } \\
\text { CD, identifying different genres, categorizing different arts, } \\
\text { accessibility for various arts across different parts of Iran. }\end{array}$ \\
\hline Applying & $\begin{array}{l}\text { Transferring the experiences of past generation to new generation, } \\
\text { branding the existing arts, tourist attraction, presenting the artworks } \\
\text { abroad, presenting as courses in universities globally. }\end{array}$ \\
\hline Others & $\begin{array}{l}\text { Advertisement to attract new generation; financial support to } \\
\text { recognize masters; advertisement to attract traditional masters for } \\
\text { collaboration; free workshops to promote existing arts }\end{array}$ \\
\hline
\end{tabular}

\section{CONCLUSION}

Based on review of previous researches on knowledge management, it was concluded that important KM practices include transferring, storing, generating and also applying. After conducting the interview, due to finding the necessary solutions to use these practices in arts, different outcomes have been achieved (Table 1). At first, interviewees considered government support as the most important kind of support. Moreover, support by ministry of culture, schools and universities as well as art institute's play key roles in supporting and responsibility.

For the achieved results above, motivation in old and new generations is very critical. New generation and new talents should be identified in order to receive the experiences of old experts. In addition, old experts should be supported financially so that they will be willing to collaborate with other artists and also will share their experiences with students.

Future researches can study the achieved factors from interview with more details. For example, the effective factors on knowledge/art sharing in a quantitative research should be analyzed. Besides, a similar research can be performed for a specific art such as music.

\section{REFERENCES}

Alavi, M., \& Leidner, D. (2001). Knowledge management and knowledge management systems: Conceptual foundations and research issues. MIS Quarterly, 25(1), 107-136.

Alavi, M., \& Tiwana, A. (2003). Knowledge management: The information technology dimension. In M. Easterby-Smith, \& M.A. Lyles (Eds.), Organizational learning and knowledge management (pp. 104-121). London: Blackwell Publishing.

Amit, R., \& Schoemaker, P. J. (1993). Strategic assets and organizational rent. Strategic Management Journal, $14,33-46$.

Argote, L., \& Ingram, P. (2000). Knowledge transfer: A basis for competitive advantage in firms. Organizational behavior and human decision processes, 82(1), 150169 .

Baum, J. A., Li, S. X., \& Usher, J. M. (2000). Making the next move: How experiential and vicarious learning shape the locations of chains' acquisitions. Administrative Science Quarterly, 45, 766-801.

Capon, N., Farley, J. U., Lehman, D. R., \& Hulbert, J. M. (1992). Profiles of product innovators among large US manufacturers. Management Science, 38(2), $157-$ 168.

Darroch, J., \& McNaughton, R. (2002). Examining the link between knowledge management practice and types of innovation. Journal of Intellectual Capital, 3(3), $210-222$.

DeCarolis, D.M., \& Deeds, D. (1999). The impact of stocks and flows of organizational knowledge on firm performance: An empirical investigation of the biotechnology industry. Strategic Management Journal, 20, 953-968.

Donate, M. J., \& de Pablo, J. D. S. (2015). The role of knowledge-oriented leadership in knowledge management practices and innovation. Journal of Business Research, 68(2), 360-370.

$\mathrm{Du}$ Plessis, M. (2007). The role of knowledge management in innovation. Journal of Knowledge Management, 11(4), 20-29.

Grant, R. M. (1996). Toward a knowledge based theory of the firm. Strategic Management Journal, 17(Special Issue), 109-122.

Grant, R. M. (2002). Contemporary strategy analysis. Concepts, techniques and applications (4th ed.). Boston: Blackwell Publishers.

Kogut, B., \& Zander, U. (1992). Knowledge of the firm, combinative capabilities and replication of technology. Organization Science, 3(3), 383-397.

Li, T., \& Calantone, R. J. (October, 1998). The impact of market knowledge competence on new product advantage: Conceptualization and empirical examination. Journal of Marketing, 62, 13-29. 
Lynn, G. S., Reilly, R. R., \& Akgun, A. E. (2000). Knowledge management in new product teams: Practices and outcomes. IEEE Transaction on Engineering and Management, 47(2), 221-231.

Manafi, M., \& Subramaniam, I. D. (2015). Relationship between Human Resources Management Practices, Transformational Leadership, and Knowledge Sharing on Innovation in Iranian Electronic Industry. Asian Social Science, 11(10), 358.

March, J. G. (1991). Exploration and exploitation in organizational learning. Organization Science, 2(1), 7187.

Nguyen, H. N., \& Mohamed, S. (2011). Leadership behaviors, organizational culture and knowledge management practices: An empirical investigation. Journal of Management Development, 30(2), 206-221.

Nonaka, I., \& Konno, N. (1998). The concept of "Ba": Building a foundation for knowledge creation. California Management Review, 40(3), 40-54.

Nonaka, I., \& Takeuchi, H. (1995). The knowledge creating company: How Japanese companies create the dynamics of innovation. New York: Oxford University Press.
Raisch, S., \& Birkinshaw, J. (2008). Organizational ambidexterity: Antecedents, outcomes, and moderators. Journal of Management, 34(3), 375-409.

Subramaniam, M., \& Youndt, M. (2005). The influence of intellectual capital on the types of innovative capabilities. Academy of Management Journal, 48(3), $450-463$.

Zack, M., McKeen, J., \& Singh, S. (2009). Knowledge management and organizational performance: An exploratory survey. Journal of Knowledge Management, 13(6), 392-409.

Zahra, S. A., \& Bogner,W. C. (1999). Technology strategy and software new venture's performance: Exploring themoderating effect of the competitive environment. Journal of Business Venturing, 15(2), $135-173$.

Zahra, S. A., \& Das, S. R. (1993). Innovation strategy and financial performance in manufacturing companies: An empirical study. Production and Operations Management, 2(1), 15-37. 